\title{
Jacques Charles Lemaire, Premières attestations lexicales dans le "Mystère de Sainte Barbe en cinq journées"
}

\section{Paola Cifarelli}

\section{(2) OpenEdition \\ Journals}

Édition électronique

URL : http://journals.openedition.org/studifrancesi/6222

DOI : 10.4000/studifrancesi.6222

ISSN : 2427-5856

Éditeur

Rosenberg \& Sellier

Édition imprimée

Date de publication : 1 novembre 2010

Pagination : 537

ISSN : 0039-2944

\section{Référence électronique}

Paola Cifarelli, « Jacques Charles Lemaire, Premières attestations lexicales dans le "Mystère de Sainte Barbe en cinq journées" », Studi Francesi [En ligne], 162 (LIV | III) | 2010, mis en ligne le 30 novembre 2015, consulté le 13 janvier 2021. URL : http://journals.openedition.org/studifrancesi/6222 ; DOI : https://doi.org/10.4000/studifrancesi.6222

Ce document a été généré automatiquement le 13 janvier 2021.

\section{cc) (†) $\odot$}

Studi Francesi è distribuita con Licenza Creative Commons Attribuzione - Non commerciale - Non opere derivate 4.0 Internazionale. 


\title{
Jacques Charles Lemaire, Premières attestations lexicales dans le "Mystère de Sainte Barbe en cinq journées"
}

\author{
Paola Cifarelli
}

\section{RÉFÉRENCE}

JACQUES CHARLES LEMAIRE, Premières attestations lexicales dans le "Mystère de Sainte Barbe en cinq journées", «Romania» 507-508, 2009, fasc. 3-4, pp. 500-510.

1 Conservé dans trois manuscrits (Paris, BnF, fr. 976, fr. 24335-24339 et Arsenal 3496-3497, les deux derniers remontant au XVIII ${ }^{\mathrm{e}}$ siècle), le Mystère de Sainte Barbe en cinq journées atteste de la popularité dont a joui la sainte jusqu'au $\mathrm{XVI}^{\mathrm{e}}$ siècle et même audelà. L'A., qui prépare l'édition critique de ce texte, analyse ici les premières attestations lexicales, concentrées surtout dans les deux premières journées et liées particulièrement aux parties du texte dans lesquelles la sainte défend le catholicisme contre les païens; il s'arrête en particulier sur les adjectifs impréhensible, vassileuse, legible, judiciable, aux substantifs superficiosité (apparence), trinaire, neccessitacion, souleur, maculacion, au verbe grognasser, à la locution goute grappe. Cette collecte atteste de l'intérêt lexicographique de cette pièce, jouée plusieurs fois entre 1448 et 1493 dans le Nord de la France. 